\title{
Bioinformatics and 3D homology modelling of AsAlaDH from Amycolatopsis sulphurea
}

\author{
Fatih $\operatorname{Aktaş}^{1 *}$ \\ 1*Düzce University, Faculty of Engineering, Department of Environmental Engineering, Düzce, Turkey (ORCID: 0000-0002-2031-298X), fatihaktas@ duzce.edu.tr
}

(First received 14 June 2021 and in final form 30 August 2021)

(DOI: $10.31590 /$ ejosat.971416)

ATIF/REFERENCE: Aktaş, F. (2021). Bioinformatics and 3D homology modelling of AsAlaDH from Amycolatopsis sulphurea. European Journal of Science and Technology, (25), 829-835.

\begin{abstract}
Alanine dehydrogenase (AlaDH) (E.C.1.4.1.1) is an enzyme that catalyzes the interconversion of pyruvate and alanine. This enzyme has the key catalytic role for the sporulation of microorganisms and synthesis of the many amino acids, proteins, and peptidoglycan layers in the microorganisms. Amycolatopsis sulphurea one of the strains of Amycolatopsis genus within the family Pseudonocardiaceae has capable to produce different antibiotics such as Ristocetin, Vancomycin, and Epoxyquinomicin as well as to biodegrade the bioplastic (poly-lactic acid (PLA) films). The 3D homology model of Alanine dehydrogenase from Amycolatopsis sulphurea was carried out through I-TASSER. The interaction of L-alanine and active site amino acids of the enzyme was determined by docking in silico via AutoDock Vina program. Protein secondary structures were predicted with EMBOSS tool garnier. Structural and functional analysis and determination of Physico-chemical properties of AsAlaDH were performed by using different bioinformatics tools. The secondary structure and multiple alignment analysis of alanine dehydrogenase displayed that there are conserved amino acid residues of AlaDH's from different microorganisms.
\end{abstract}

\section{Amycolatopsis sulphurea'dan Elde Edilen AsAlaDh'ın 3D Modellemesi ve Biyoinformatiği}

Öz

\begin{abstract}
Alanin dehidrogenaz (AlaDH) (E.C.1.4.1.1), piruvat ve alaninin birbirine dönüşümünü katalize eden bir enzimdir. Bu enzim, mikroorganizmanın sporlanması ve mikroorganizmalardaki birçok amino asit, protein ve peptidoglikan tabakasının sentezi için anahtar katalitik role sahiptir. Amycolatopsis sulphurea, Pseudonocardiaceae familyası içindeki Amycolatopsis cinsinin suşlarından biri olup, Ristosetin, Vankomisin ve Epoksiquinomisin gibi farklı antibiyotikler üretmenin yanı sıra biyoplastik (poli-laktik asit (PLA) filmlerini biyolojik olarak parçalama yeteneğine sahiptir). Amycolatopsis sulphurea'dan Alanin dehidrogenazın 3D homoloji modeli ITASSER aracılığıyla gerçekleştirildi. L-alanin ile enzimin aktif bölge amino asitlerinin etkileşimi, AutoDock Vina programı ile in silico kenetlenerek belirlendi. Protein ikincil yapıları EMBOSS tool garnier ile tahmin edildi. AsAlaDH'nin yapısal ve fonksiyonel analizleri ve fiziko-kimyasal özelliklerinin belirlenmesi farklı biyoinformatik araçlar kullanılarak gerçekleştirilmiştir. Alanin dehidrogenazın ikincil yapısı ve çoklu hizalama analizi, AlaDH'lerin farklı mikroorganizmalardan korunmuş amino asit kalıntıları olduğunu göstermiştir.
\end{abstract}

Anahtar Kelimeler: Alanine dehidrogenaz, Amycolatopsis sulphurea, 3D homoloji modelleme, biyokatalist*

${ }^{*}$ Corresponding Author: fatihaktas@ duzce.edu.tr 


\section{Introduction}

Amycolatopsis sulphurea is a bacterium belongs to the Amycolatopsis genus that one of the well-defined taxa in the Pseudonocardiaceae family and Actinobacteria phylum (Lee, 2009). This bacterium was named by Lechevalier et al. (LECHEVALIER, PRAUSER, LABEDA, \& RUAN, 1986) and has yellowish-green aerial hyphae, lysozyme resistant, and the $\mathrm{G}+\mathrm{C}$ content of the type-strain genome is $69.4 \%$ (Nouioui et al., 2018). The species of this genus was defined well up to now and many novel species have been described from different sources such as freshwater, soil, and underground sites(SaintpierreBonaccio, Amir, Pineau, Tan, \& Goodfellow, 2005; Tan, Ward, \& Goodfellow, 2006). Chelocardin, one of the important antibiotics, is produced by Amycolatopsis sulphurea. it has antibacterial activity against both Gram-negative, Gram-positive bacteria, and most multi-resistant pathogens (Lukežič et al., 2013).

Alanine dehydrogenase (AlaDH, EC 1.4.1.1) catalyzes the reversible oxidative deamination of L-alanine to pyruvate reaction and it has been using for different applications in food, pharma, and biotechnological industries. This enzyme's systematic name is L-alanine: $\mathrm{NAD}^{+}$oxidoreductase (deaminating), and also has common names as L-alanine dehydrogenase (L-AlaDH), NADH-dependent alanine dehydrogenase, $\mathrm{NAD}^{+}$-linked alanine dehydrogenase, and $\mathrm{NAD}^{+}$-dependent alanine dehydrogenase. It belongs to the group of oxidoreductases and its forward reaction is oxidative deamination of alanine to pyruvate and its reverse reaction is reductive amination of pyruvate to alanine(Dave \& Kadeppagari, 2019; Yoshida \& Freese, 1965).

The principal role of AlaDHs in microorganisms has been catalyzing the oxidation of organic molecules such as pyruvate that substantial energy molecule essential for the growth of organisms (Voet, Voet, \& Pratt, 2016). It also provides a linkage between amino acid and carbohydrate metabolisms in different microorganisms as key factors in carbon and nitrogen metabolism (McCowen \& Phibbs, 1974). The kinetic properties and reaction mechanism of this enzyme have been studied in microorganisms (mostly in Bacillus species, bacteroid, heterocyst, mycelium, and hypha.) (Allaway et al., 2000; Gräfe, Bocker, Reinhardt, Tkocz, \& Thrum, 1974; Keradjopoulos \& Holldorf, 1979; Nitta, Yasuda, Tochikubo, \& Hachisuka, 1974; Pernil, Herrero, \& Flores, 2010; Porumb et al., 1987; Schultz \& Benson, 1990). A crystal structure, catalytic mechanism, and multiple sequence alignment analysis of AlaDHs from various microorganisms showed that four amino acid residues Arg-15, Lys-75 (pyruvate binding residues) (Phogosee, Hibino, Kageyama, \& Waditee-Sirisattha, 2018), His-96, and Asp-269 (or 270) (putative acid-base catalysts) highly conserved are potential residues of $\mathrm{AlaDH}$ involved in the catalytic activity (Jeong, Baek, Kim, Choi, \& Oh, 2013). The studies on AlaDH active site showed that His96 is used for changing protein conformation, and Asp270 provides the stability of the ribose of $\mathrm{NADH}$ and nicotinamide ring via hydrogen bond interactions (Ling et al., 2014; Ling, Sun, Bi, Jing, \& Liu, 2012).

lapideum, PDBID: 1PJB; Tt: Thermus thermophilus, PDBID: 2EEZ) (Sievers et al., 2011). Protein secondary structures were predicted with EMBOSS tool garnier and the figure was created
A tremendous quantity of DNA sequence data and their databases has been growing exponentially in the last decades. The field of bioinformatics studies has increased to analyze huge data containing lots of genomes from both prokaryotes and eukaryotes. The bioinformatics tools have been developed quickly to determine genes of functional proteins and RNA (Rehm \& Reinecke, 2005). The undetermined pathways of numerous unknown useful pharmaceutical and agricultural products of plenty of prokaryotic and eukaryotic organisms have been revealed by using Bioinformatics tools throughout predicted studies of them (McClerren et al., 2006; Naveed, Ahmed, Khalid, \& Mumtaz, 2014). Although prediction of Protein 3D-structure folding by using a simple sequence of amino acids had many problems in the past, it has developed rapidly to an applicable online computational resources with amenable in most cases (Haddad, Adam, \& Heger, 2020). The presence of bioinformatic tools in internet provides a great opportunity to define the physicochemical properties of enzymes including their primary, secondary and 3D structural properties. The aim of this study was primarily to report the bioinformatics and 3D homology characterization of AsAlaDH by used some different tools for the prediction of protein structure and function and active site analysis.

\section{Material and Method}

\subsection{Determination of Physico-Chemical Properties of AsAlaDH}

Protein sequences were obtained from UniProtKB and 3D structures from the protein data bank (PDB) databases. Different bioinformatics tools were used for calculating the Physicochemical properties of AsAlaDH protein sequence. Molecular weight, isoelectric point, average residue weight, and charge of protein were determined by Emboss Pepstats (Madeira et al., 2019), instability index, atomic composition, and amino acid composition were calculated by ProtParam (Wilkins et al., 1999).

\subsection{Structural and Functional Analysis of AsAlaDH}

The prediction of the secondary structure of As AlaDH protein was carried out by using PSIPred (Buchan \& Jones, 2019). Functional sites of AsAlaDH protein were defined by InterProScan (Zdobnov \& Apweiler, 2001).

\subsection{The 3D Homology Model of As AlaDH}

The 3D homology model of Amycolatopsis sulphurea alanine dehydrogenase was generated through I-TASSER (Yang et al., 2015) using the published structure of Mycobacterium tuberculosis L-alanine dehydrogenase (Mt, PDBID: 2VHX) (Agren et al., 2008) as a template. L-alanine substrate was docked into As AlaDH active site pocket in silico via AutoDock Vina (Trott \& Olson, 2010). Figures were carried out by PyMOL (Molecular Graphics System, Version 2.0 Schrodinger, LLC). Amino acid sequences of characterized AlaDHs from PDB were aligned with Clustal Omega and the figure was created with Geneious software. (As: Amycolatopsis sulphurea; Mt: Mycobacterium tuberculosis, PDBID: 2VHX; Pl: Phormidium with Geneious software. (As: Amycolatopsis sulphurea; Mt: Mycobacterium tuberculosis, PDBID: 2VHX; Pl: Phormidium lapideum, PDBID: 1PJB; Tt: Thermus thermophilus, PDBID: 
2EEZ) (Sievers et al., 2011). Protein secondary structures were predicted with EMBOSS tool garnier and the figure was created with Geneious software (Garnier, Osguthorpe, \& Robson, 1978; Rice, Longden, \& Bleasby, 2000).

Table 1. Amino acid and atomic composition of AsAlaDH determined by ProtParam

\begin{tabular}{|c|c|}
\hline \multicolumn{2}{|c|}{ Amino acid composition } \\
\hline Ala (A) 49 & $13.2 \%$ \\
\hline $\operatorname{Arg}(\mathrm{R}) 21$ & $5.7 \%$ \\
\hline $\operatorname{Asn}(\mathrm{N}) 10$ & $2.7 \%$ \\
\hline Asp (D) 21 & $5.7 \%$ \\
\hline Cys (C) 2 & $0.5 \%$ \\
\hline Gln (Q) 7 & $1.9 \%$ \\
\hline Glu (E) 20 & $5.4 \%$ \\
\hline Gly (G) 35 & $9.4 \%$ \\
\hline His $(\mathrm{H}) 12$ & $3.2 \%$ \\
\hline Ile (I) 13 & $3.5 \%$ \\
\hline Leu (L) 41 & $11.1 \%$ \\
\hline Lys (K) 10 & $2.7 \%$ \\
\hline Met (M) 5 & $1.3 \%$ \\
\hline Phe (F) 6 & $1.6 \%$ \\
\hline Pro (P) 24 & $6.5 \%$ \\
\hline $\operatorname{Ser}(S) 18$ & $4.9 \%$ \\
\hline Thr (T) 24 & $6.5 \%$ \\
\hline $\operatorname{Trp}(\mathrm{W}) 2$ & $0.5 \%$ \\
\hline $\operatorname{Tyr}(Y) 9$ & $2.4 \%$ \\
\hline $\operatorname{Val}(\mathrm{V}) 42$ & $11.3 \%$ \\
\hline Pyl (O) 0 & $0.0 \%$ \\
\hline $\operatorname{Sec}(\mathrm{U}) \quad 0$ & $0.0 \%$ \\
\hline \multicolumn{2}{|c|}{ Atomic composition } \\
\hline Carbon & 1726 \\
\hline Hydrogen $\mathrm{H}$ & 2777 \\
\hline Nitrogen $\mathrm{N}$ & 487 \\
\hline Oxygen $\mathrm{O}$ & 522 \\
\hline Sulfur $\quad S$ & 7 \\
\hline
\end{tabular}

\section{Results and discussion}

\subsection{Identification and Physico-chemical Properties of $A s \mathrm{AlaDH}$}

AsAlaDH molecular weight calculated as $38927.4 \mathrm{~g}$, with the average residual weight of $104.9 \mathrm{~g}$, the isoelectric point of 5.9, and the net charge of -4.0 by used Emboss Pepstats tool. This protein composed of 371 amino acids with 41 (Asp + Glu) negative charge residues and 31 (Arg + Lys) positive charge residues, besides higher contents of alanine, leucine and valine were showed by the ProtParam tool. The molecular formula of As AlaDH protein was observed as $\left(\mathrm{C}_{1726} \mathrm{H}_{2777} \mathrm{~N}_{487} \mathrm{O}_{522} \mathrm{~S}_{7}\right)$ that has also 5519 atoms by using the same tool. Amino acid and atomic composition of As AlaDH were shown in Table 1.
It was estimated to be AsAlaDH has six subunits that have 371 residues in each one has a $40 \mathrm{kDa}$ as considered in many members of the enzyme family in literature (Tripathi \& Ramachandran, 2008). There are a total of $16 \alpha$-helices and 16 $\beta$-strands in each subunit as shown in figure 1 .

\subsection{Structural analysis and Functional domain prediction of AsAlaDH}

PSIPRED server was used to define the secondary structure of $A s \mathrm{AlaDH}$. The results represented that $A s \mathrm{AlaDH}$ primarily arranged of beta-strands, alfa-helix, and coils (Figure 1). There are a total of $16 \alpha$-helices and $16 \beta$-strands in each subunit as shown in figure 1.

InterProScan was showed that it has two Alanine dehydrogenase/pyridine nucleotide transhydrogenase (PNT), Nterminal domain sites (in between 4-137 as N-terminal domain, and 141-352 residues as $\mathrm{NAD}(\mathrm{H})$-binding domain) and represented good functional homology with $\mathrm{NAD}(\mathrm{P})$-binding domain superfamily (137-303 residues). It was indicated that it has L-alanine metabolic process (GO:0042853) and alanine dehydrogenase activity (GO:0000286).

\subsection{The 3D homology model of AsAlaDH}

The 3D homology model of AsAlaDH was created through I-TASSER using Mycobacterium tuberculosis L-alanine dehydrogenase (Mt, PDBID: 2VHX) as a template with $63.34 \%$ identity. Despite AsAlaDH and MtAlaDH $61 \%$ sequence similarity, both enzymes have conserved substrate-binding pocket and active side residues. (Figure 2).

Active site comparison of AsAlaDH (gray) and MAlaD (blue), displaying pretty identical active site construction and similar amino acid residues near the L-alanine substrate. The substrate L-alanine was bound in the active site of $A s \mathrm{AlaDH}$ through H-bonds with $\operatorname{Arg} 15$ (NH1-2.9 $\AA$ and NH2-3.3 $\AA$ ), Lys75 (NZ-2.8 $\AA$ ), Tyr94 (CZ-2.7 $\AA$ and CD2-3.5 $\AA$ ), His96 (NE2-2.7 and 2.9 $\AA$ ) and Asn300 (ND2-3.2 $\AA$ ) in the AsAlaDH structure (Figure 3 ).

\section{Conclusions and Recommendations}

In our study, we have determined Physico-chemical properties, structural and functional analysis, and the 3D homology model of As AlaDH using some bioinformatics databases and tools. Our data showed that $A s \mathrm{AlaDH}$ has similar catalytic sites and amino acid distributions have few changes. This suggests that As AlaDH belongs to the NAD+/NADH-dependent alanine dehydrogenase group involved in recognition and binding substrate site and catalytic site.

The active site comparison and functional domain prediction of AsAlaDH studies presented here provide this enzyme as a good candidate for obtaining fine chemicals and amino acids for the prodrug and chemical industry. Our findings prove that the structural and functional regions of this enzyme, which we have experimentally recent studied (Aktaş, 2021), belong to the Lamino acid dehydrogenase group. 
1 MR I A V P RE I KR REYRVAL T PA GV HELV GRGHDVFVETTQAGAGSSI T DEE Y 50 V A A G A K K V L A T A E E T W S E G E L V L K V K E P I A D E E Y P R L R K D L V L F T Y L H I A A D D 100

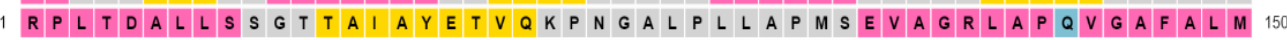
151 K P S G G R G V L P G G I P G V H P A R V V V I G G G V A G L N A A R V A L G

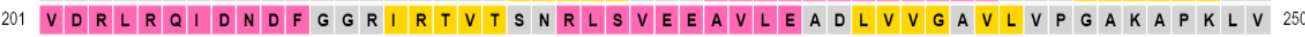

251 S N D L V S R M K P G S V L V D I A I D Q G G C F A D S R P T T H D D P T Y R V H E S V F Y C V A A N 300

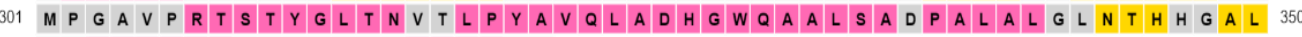

351 T N A P

\begin{tabular}{|c|c|c|c|}
\hline Strand & Helix & Coil & Disordered \\
\hline Disordered, protein binding & Putative Domain Boundary & Membrane Interaction & Transmembrane Helix \\
\hline Extracellular & Re-entrant Helix & Cytoplasmic & Signal Peptide \\
\hline
\end{tabular}

b

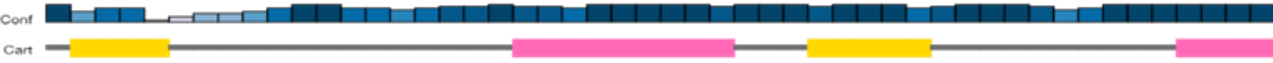

Prod CEEEECCCCCCCCCCCCCCHHHHHHHHHCCCEEEEECCCCCCCCCCHHHH AA MRI AVPREI KRHEYRVALTPAGVHELVGRGHDVFVETQAGAGSSITDEEY 10 30

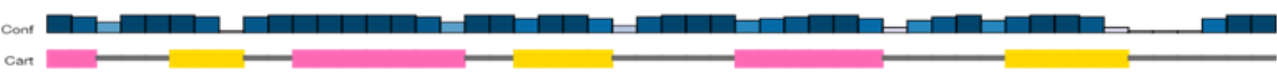

PHHCC CEEECCHHHHHHHCCEEEECCCCCHHHHHHCCCCCEEEEEC C C C C A VAAGAKVLATAEETWSEGELVLKVKEPI ADEYPRLRKDLVLFTYLHIAAD

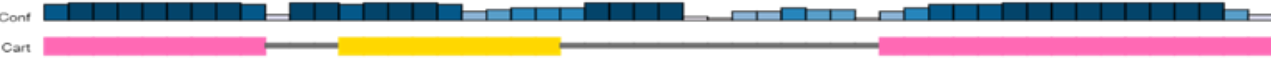

Prod H H H H H H H C CEEEEEEEEECCC C C C C C C C C A RPLTDALLSSGTTAI AYETVQKPNGALPLLAPMSEVAGRLAPQVGAFALM 130 140

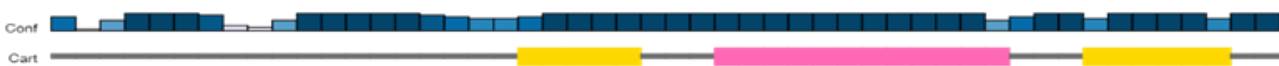

Prod C C C C C C C C C C C C C C CEEEEECCCHHHHHHHHHHHHCCCEEEEECC AA KPSGGRGVLPGGI PGVHPARVVVI GGGVAGLNAARVALGLGSDVEILDTN 100 170

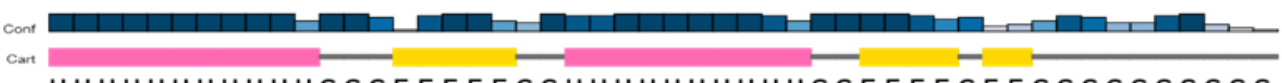

Prod $\mathrm{HH}$ H H H H H H H C CEEEEECCHHHHHHHHHHCCEEEECEECCCCCCCC C AL VDRLROI DNDFGGRI RTVTSNRLSVEOAVLEADLVVGAVLVPGAKAPKLV 210 220 230 240

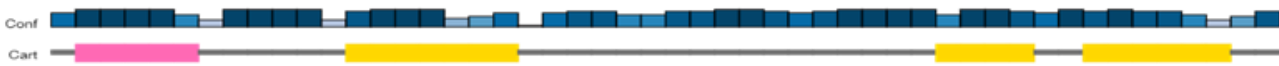

Prod CHHHHHCCCCCCEEEEEEECCCCCCCCCCCCCCCCCEEEECCEEEEECC AA SNDLVSRMKPGSVLVDIAI DQGGCFADSRPTTHDDPTYRVHESVFYCVAN 200 270

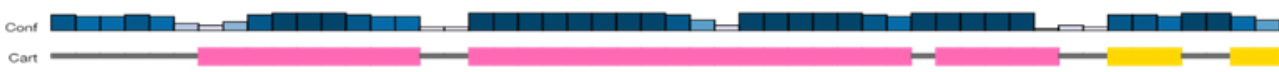

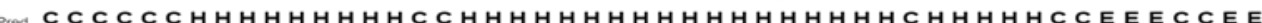

AA MPGAVPRTSTYGLTNVTLPYAVQLADHGWQAALSADPALALGLNTHHGAL 320 330

Cont

AA TNAPVAAAHDLPHTALETVLS

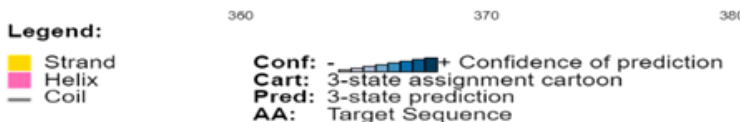
AA: Target Sequence

Figure 1. The prediction of the secondary structure ( $\alpha$-helix, $\beta$-strand, and coil structures) of AsAlaDH protein was carried out by using PSIPred. A: Amino acid residues in each secondary structure ( $\beta$-strand (yellow), $\alpha$ - helix (pink), coil (grey)) B: 3-state assignment cartoon exhbitbition ( $\beta$-strand (yellow), $\alpha$ - helix (pink), coil (grey)). 


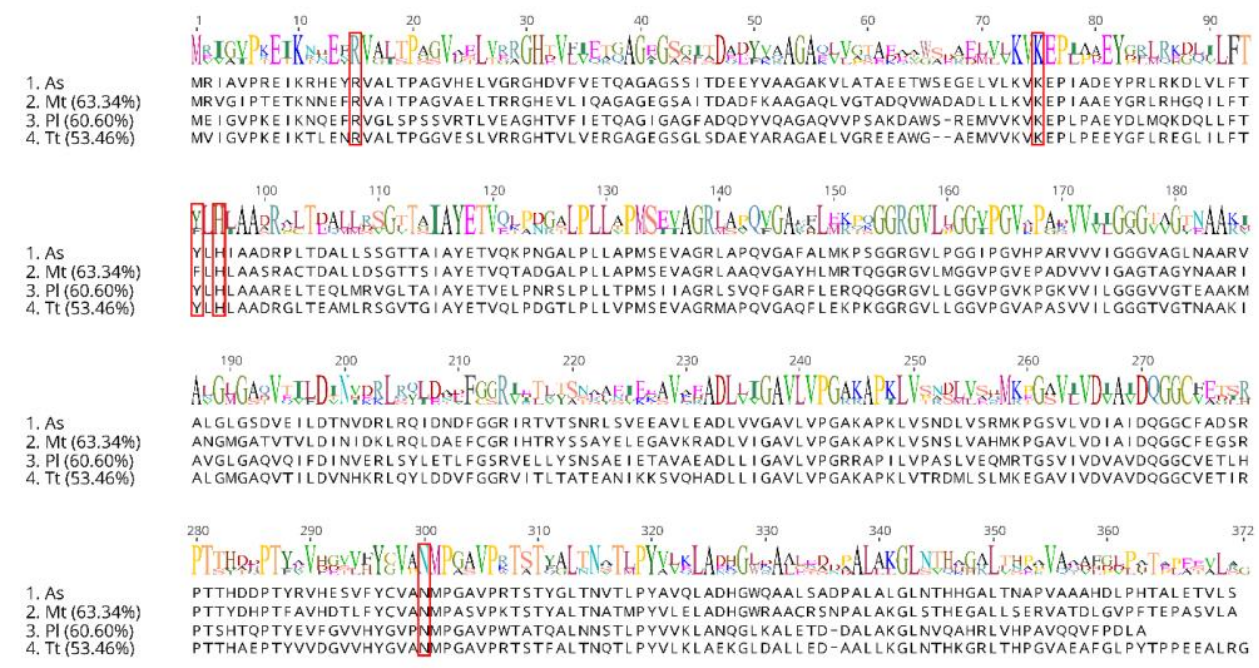

Figure2. Multiple amino acid sequence alignments of AlaDHs. Percentages indicates the sequence identity between AsAlaDH and isozyme AlaDHs (As: Amycolatopsis sulphurea; Mt: Mycobacterium tuberculosis; Pl: Phormidium lapideum; Tt: Thermus thermophilus). The residues constructing the active site pocket are indicated in red rectangles

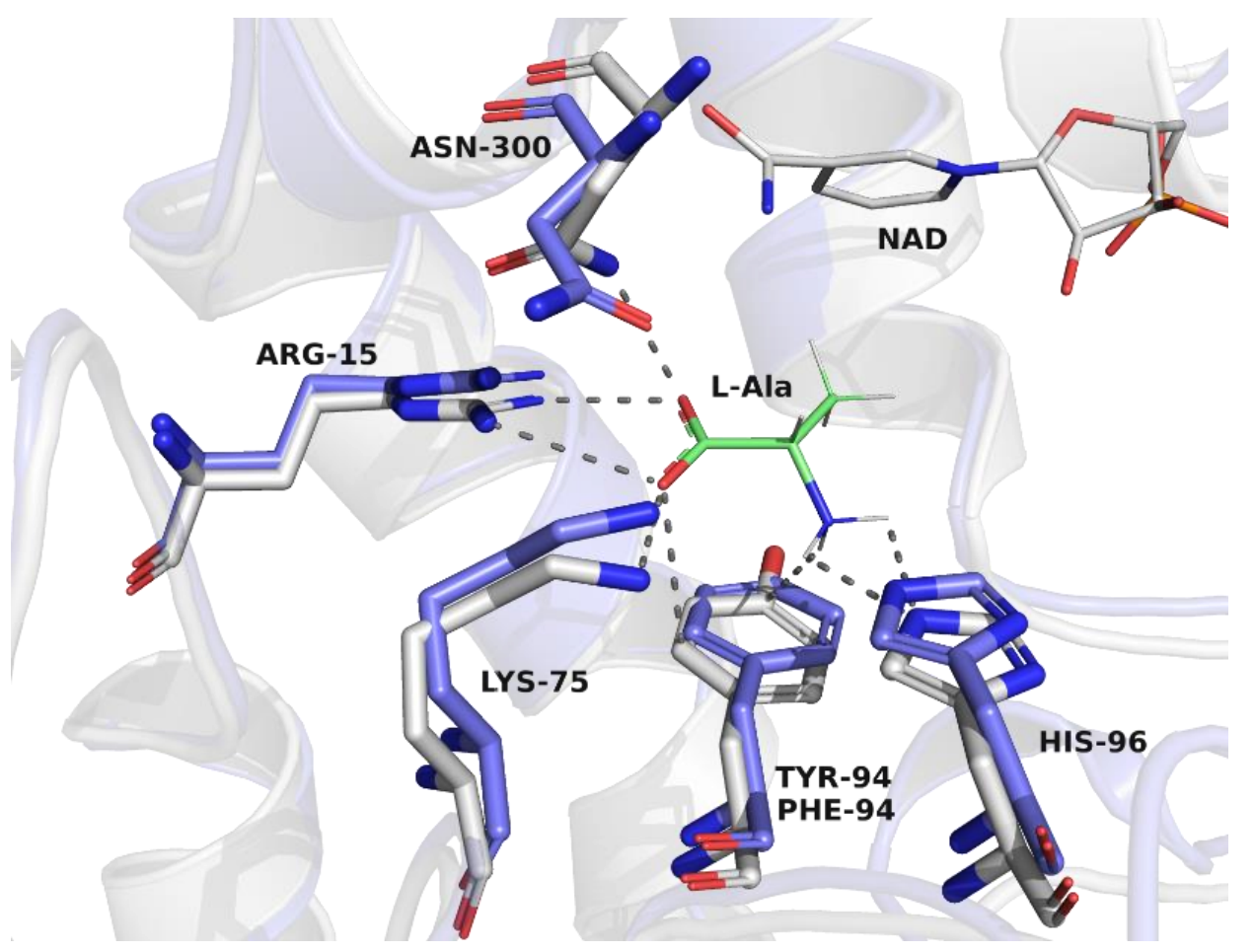

Figure 3. Homology model of AsAlaDH superimposed with the structure of $M t \mathrm{AlaDH}$ (PDB ID: $2 \mathrm{VHX}$ ). $\mathrm{NAD}^{+}$cofactor, active site and homology models of $A s \mathrm{AlaDH}$ and $M t \mathrm{AlaDH}$ enzymes, docked L-alanine substrate shown in gray, blue, green, respectively.

All these results with, active site mutation studies and protein engineering techniques will enable the AsAlaDH enzyme to be used as a stable and efficient enzyme in biotechnological applications.

In this study, we have considered only in silico studies for AsAlaDH to discover enzyme structure-function environment and relationship. In future research, more biochemical and enzymatic characterization can be studied to be able to improve enzyme catalytic efficiency and substrate specificity.

\section{References}

Agren, D., Stehr, M., Berthold, C. L., Kapoor, S., Oehlmann, W., Singh, M., \& Schneider, G. (2008). Threedimensional structures of apo- and holo-L-alanine dehydrogenase from Mycobacterium tuberculosis reveal conformational changes upon coenzyme binding. $\mathrm{J}$ Mol Biol, 377(4), 1161-1173. doi:10.1016/j.jmb.2008.01.091

Aktaş, F. (2021). Heterologous Expression and Partial Characterization of a New Alanine Dehydrogenase from Amycolatopsis sulphurea. The Protein Journal, 40(3), 342-347. doi:10.1007/s10930-021-09982-9

Allaway, D., Lodwig, E. M., Crompton, L. A., Wood, M., Parsons, R., Wheeler, T. R., \& Poole, P. S. (2000). 
Identification of alanine dehydrogenase and its role in mixed secretion of ammonium and alanine by pea bacteroids. Mol Microbiol, 36(2), 508-515. doi:10.1046/j.1365-2958.2000.01884.x

Buchan, D. W. A., \& Jones, D. T. (2019). The PSIPRED Protein Analysis Workbench: 20 years on. Nucleic acids research, 47(W1), W402-W407. doi:10.1093/nar/gkz297 $\%$ J Nucleic Acids Research

Dave, U. C., \& Kadeppagari, R.-K. (2019). Alanine dehydrogenase and its applications - A review. Critical Reviews in Biotechnology, 39(5), 648-664. doi:10.1080/07388551.2019.1594153

Garnier, J., Osguthorpe, D. J., \& Robson, B. (1978). Analysis of the accuracy and implications of simple methods for predicting the secondary structure of globular proteins. J Mol Biol, 120(1), 97-120. doi:https://doi.org/10.1016/0022-2836(78)90297-8

Gräfe, U., Bocker, H., Reinhardt, G., Tkocz, H., \& Thrum, H. (1974). [Activity of alanine dehydrogenase and production of antibiotic in cultures of Streptomyces hygroscopicus JA 6599 (author's transl)]. Z Allg Mikrobiol, 14(3), 181-192. doi:10.1002/jobm.3630140302

Haddad, Y., Adam, V., \& Heger, Z. (2020). Ten quick tips for homology modeling of high-resolution protein 3D structures. PLOS Computational Biology, 16(4), e1007449. doi:10.1371/journal.pcbi.1007449

Jeong, J.-A., Baek, E.-Y., Kim, S. W., Choi, J.-S., \& Oh, J.-I. (2013). Regulation of the <em $>$ ald $</$ em $>$ Gene Encoding Alanine Dehydrogenase by AldR in <span class="namedcontent genus-species" id="named-content$1 ">$ Mycobacterium smegmatis</span $>$. 195(16), 36103620. doi:10.1128/JB.00482-13 \% J Journal of Bacteriology

Keradjopoulos, D., \& Holldorf, A. W. (1979). Purification and properties of alanine dehydrogenase from Halobacterium salinarium. Biochimica et biophysica acta, 570(1), 1-10. doi:10.1016/0005-2744(79)90195-5

Lechevalier, M. P., Prauser, H., Labeda, D. P., \& Ruan, J.-S. (1986). Two New Genera of Nocardioform Actinomycetes: Amycolata gen. nov. and Amycolatopsis gen. nov. 36(1), 29-37. doi:https://doi.org/10.1099/00207713-36-1-29

Lee, S. D. (2009). Amycolatopsis ultiminotia sp. nov., isolated from rhizosphere soil, and emended description of the genus Amycolatopsis. 59(6), 1401-1404. doi:https://doi.org/10.1099/ijs.0.006577-0

Ling, B., Bi, S., Sun, M., Jing, Z., Li, X., \& Zhang, R. (2014). Molecular dynamics simulations of mutated Mycobacterium tuberculosis L-alanine dehydrogenase to illuminate the role of key residues. J Mol Graph Model, 50, 61-70. doi:10.1016/j.jmgm.2014.03.008

Ling, B., Sun, M., Bi, S., Jing, Z., \& Liu, Y. (2012). Molecular dynamics simulations of the coenzyme induced conformational changes of Mycobacterium tuberculosis L-alanine dehydrogenase. J Mol Graph Model, 35, 1-10. doi:10.1016/j.jmgm.2012.01.005

Lukežič, T., Lešnik, U., Podgoršek, A., Horvat, J., Polak, T., Šala, M., . . . Petković, H. (2013). Identification of the chelocardin biosynthetic gene cluster from Amycolatopsis sulphurea: a platform for producing novel tetracycline antibiotics. Microbiology (Reading), 159(Pt 12), 25242532. doi:10.1099/mic.0.070995-0
Madeira, F., Park, Y. M., Lee, J., Buso, N., Gur, T., Madhusoodanan, N., . . . Lopez, R. (2019). The EMBLEBI search and sequence analysis tools APIs in 2019. Nucleic acids research, 47(W1), W636-W641. doi:10.1093/nar/gkz268

McClerren, A. L., Cooper, L. E., Quan, C., Thomas, P. M., Kelleher, N. L., \& van der Donk, W. A. (2006). Discovery and in vitro biosynthesis of haloduracin, a two-component lantibiotic. 103(46), $17243-17248$ doi:10.1073/pnas.0606088103\%J Proceedings of the National Academy of Sciences

McCowen, S. M., \& Phibbs, P. V. (1974). Regulation of Alanine Dehydrogenase in <em>Bacillus licheniformis</em>. 118(2), 590-597.

Naveed, M., Ahmed, I., Khalid, N., \& Mumtaz, A. S. (2014). Bioinformatics based structural characterization of glucose dehydrogenase (gdh) gene and growth promoting activity of Leclercia sp. QAU-66. Brazilian journal of microbiology : [publication of the Brazilian Society for Microbiology], 45(2), 603-611. doi:10.1590/s151783822014000200031

Nitta, Y., Yasuda, Y., Tochikubo, K., \& Hachisuka, Y. (1974). L-amino acid dehydrogenases in Bacillus subtilis spores. J Bacteriol, 117(2), 588-592. doi:10.1128/jb.117.2.588592.1974

Nouioui, I., Carro, L., García-López, M., Meier-Kolthoff, J. P., Woyke, T., Kyrpides, N. C., . . . Göker, M. (2018). Genome-Based Taxonomic Classification of the Phylum Actinobacteria. 9(2007). doi:10.3389/fmicb.2018.02007

Pernil, R., Herrero, A., \& Flores, E. (2010). Catabolic Function of Compartmentalized Alanine Dehydrogenase in the Heterocyst-Forming Cyanobacterium <em>Anabaena</em> sp. Strain PCC 7120. 192(19), 5165-5172. doi:10.1128/JB.00603-10 \%J Journal of Bacteriology

Phogosee, S., Hibino, T., Kageyama, H., \& Waditee-Sirisattha, R. (2018). Bifunctional alanine dehydrogenase from the halotolerant cyanobacterium Aphanothece halophytica: characterization and molecular properties. Arch Microbiol, 200(5), 719-727. doi:10.1007/s00203-0181481-7

Porumb, H., Vancea, D., Mureşan, L., Presecan, E., Lascu, I., Petrescu, I., . . Bârzu, O. (1987). Structural and catalytic properties of L-alanine dehydrogenase from Bacillus cereus. J Biol Chem, 262(10), 4610-4615.

Rehm, B. H. A., \& Reinecke, F. (2005). Bioinformatic Tools for Gene and Protein Sequence Analysis. In J. M. Walker \& R. Rapley (Eds.), Medical Biomethods Handbook (pp. 387-407). Totowa, NJ: Humana Press.

Rice, P., Longden, I., \& Bleasby, A. (2000). EMBOSS: the European Molecular Biology Open Software Suite. Trends Genet, 16(6), 276-277. doi:10.1016/s01689525(00)02024-2

Saintpierre-Bonaccio, D., Amir, H., Pineau, R., Tan, G. Y. A., \& Goodfellow, M. (2005). Amycolatopsis plumensis sp. nov., a novel bioactive actinomycete isolated from a NewCaledonian brown hypermagnesian ultramafic soil. International Journal of Systematic and Evolutionary Microbiology, 55(5), 2057-2061. doi:10.1099/ijs.0.636300

Schultz, N. A., \& Benson, D. R. (1990). Enzymes of ammonia assimilation in hyphae and vesicles of Frankia sp. strain 
CpI1. J Bacteriol, 172(3), 1380-1384. doi:10.1128/jb.172.3.1380-1384.1990

Sievers, F., Wilm, A., Dineen, D., Gibson, T. J., Karplus, K., Li, W., . . Higgins, D. G. (2011). Fast, scalable generation of high-quality protein multiple sequence alignments using Clustal Omega. 7(1), 539. doi:https://doi.org/10.1038/msb.2011.75

Tan, G. Y. A., Ward, A. C., \& Goodfellow, M. (2006). Exploration of Amycolatopsis diversity in soil using genus-specific primers and novel selective media. Systematic and Applied Microbiology, 29(7), 557-569. doi:https://doi.org/10.1016/j.syapm.2006.01.007

Tripathi, S. M., \& Ramachandran, R. (2008). Crystal structures of the Mycobacterium tuberculosis secretory antigen alanine dehydrogenase (Rv2780) in apo and ternary complex forms captures "open" and "closed" enzyme conformations. 72(3), 1089-1095. doi:https://doi.org/10.1002/prot.22101

Trott, O., \& Olson, A. J. (2010). AutoDock Vina: improving the speed and accuracy of docking with a new scoring function, efficient optimization, and multithreading. Journal of computational chemistry, 31(2), 455-461. doi: $10.1002 /$ jcc. 21334

Voet, D., Voet, J. G., \& Pratt, C. W. (2016). Fundamentals of biochemistry life at the molecular level.

Wilkins, M. R., Gasteiger, E., Bairoch, A., Sanchez, J. C., Williams, K. L., Appel, R. D., \& Hochstrasser, D. F. (1999). Protein identification and analysis tools in the ExPASy server. Methods in molecular biology (Clifton, N.J.).

Yang, J., Yan, R., Roy, A., Xu, D., Poisson, J., \& Zhang, Y. (2015). The I-TASSER Suite: protein structure and function prediction. Nat Methods, 12(1), 7-8. doi:10.1038/nmeth.3213

Yoshida, A., \& Freese, E. (1965). Enzymic properties of alanine dehydrogenase of Bacillus subtilis. Biochimica et Biophysica Acta (BBA) - Nucleic Acids and Protein Synthesis, 96(2), 248-262. doi:https://doi.org/10.1016/0005-2787(65)90588-5

Zdobnov, E. M., \& Apweiler, R. (2001). InterProScan - an integration platform for the signature-recognition methods in InterPro. Bioinformatics, 17(9), 847-848. doi:10.1093/bioinformatics/17.9.847 \%J Bioinformatics 